\title{
Chemical Type Variation of Groundwater in Borobudur and Surroundings Area, Magelang District
}

\author{
T. Listyani R.A.*, Sri.Ning Peni \\ Geological Engineering Department, Nasional Yogyakarta Institute of Technology
}

\begin{abstract}
Hydrogeological surveys have been carried out in the Borobudur area and its surroundings, the northern part of the West Progo Hills to the Magelang intermountain plains. The purpose of this study is to determine the variations in groundwater's chemical types in the study area and to interpret the hydrochemical processes. Primary data was taken in the field, including groundwater data and rock petrology. Physical / chemical data of groundwater were obtained from laboratory test results. Data analysis includes hydrochemical analysis using the Stiff, Piper, and Durov diagrams. The result shows that groundwater in the study area has a wide variety of chemical types, namely $\mathrm{Ca}, \mathrm{Mg}$ - bicarbonate; $\mathrm{Ca}, \mathrm{Mg}$, alkaline bicarbonate; Alkaline, $\mathrm{Ca}$ - chloride, and Alkaline - chloride. Groundwater in the study area is fresh (type Va) to brackish (type Vc), with low moderate TDS content $(119-6,810 \mathrm{ppm})$, and soft calcium carbonate hardness (6.0 - $16.6 \mathrm{ppm})$. Hydrochemical processes occur in groundwater are simple dissolution and cation exchange caused by clay materials originating from Quaternary deposits or weathering of Old Andesite Formation volcanic breccia. In addition, the presence of brackish water in Karangrejo and Candirejo may be triggered by mixing with fossil water.
\end{abstract}

\section{Introduction}

The research area is located in Borobudur and its surroundings, Magelang Regency (Fig. 1), which is included in the southern part of the Mungkid sheet map. Geographically, the study area is included in the coordinates 110.7'15 "- 110.13'45" South Latitude and 7.35'45 "7.37'40" East Longitude.

The northern research area is included in the physiography of the Java central depression or intra mountain of the Quaternary volcano, while the southern part is included in the West Progo Hills [1]. West Progo Hills physiography is a non-groundwater basin region [2]. In this area, groundwater can be found with varying quantity and quality.

In quantity, groundwater is generally quite abundant in alluvial / coluvial deposits, and only a few can be extracted from hard rock. Meanwhile, groundwater quality also shows variations from fresh to brackish. This varying quality of groundwater is characterized by different types of groundwater chemistry.

* Corresponding author: list@itny.ac.id 
Determination of the type of groundwater chemistry becomes important in hydrogeological studies. By knowing the type of groundwater chemistry, we can also provide recommendations for groundwater quality that are suitable for the local community's purpose. Good groundwater quality will have a certain type of groundwater chemistry, with certain major elemental content, according to the limits recommended by the government.

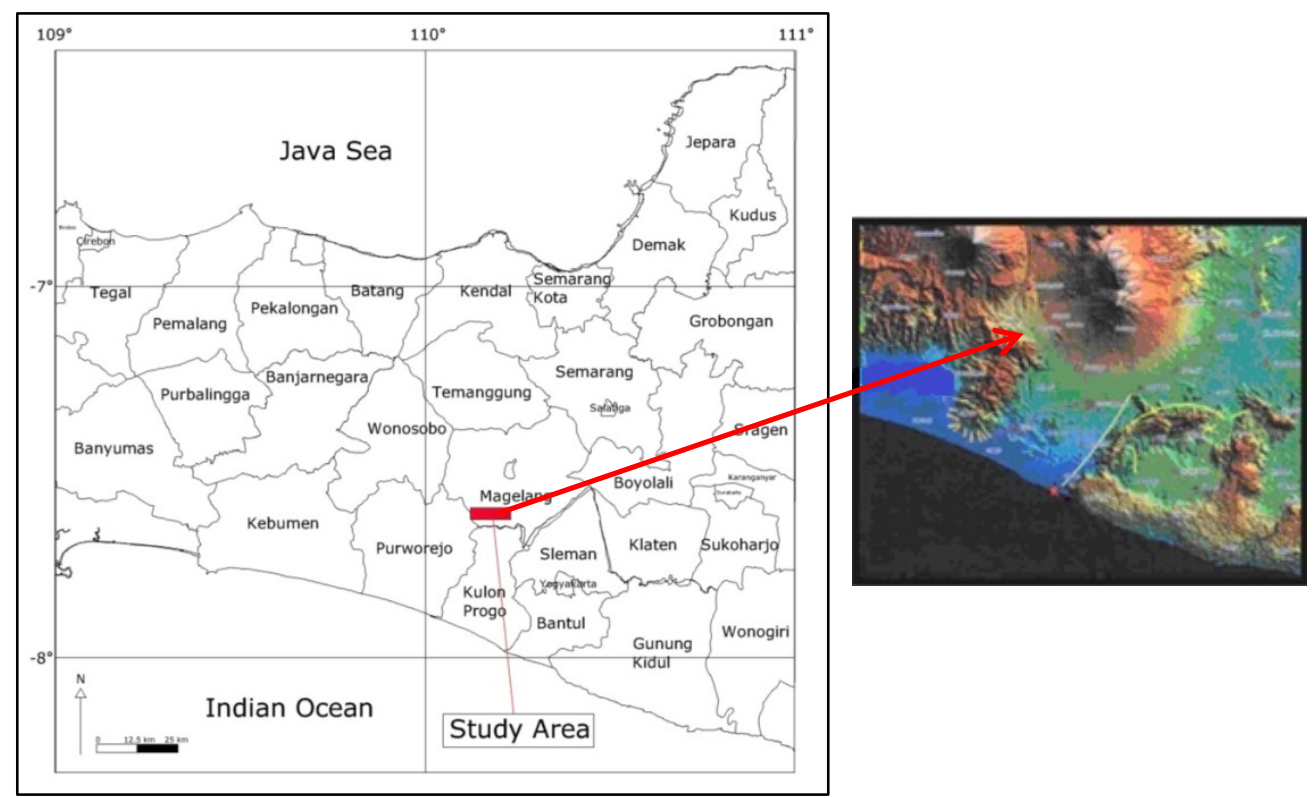

Fig. 1. Research area in Borobudur and its vicinity, Central Java

\section{Method}

Hydrogeological surveys in the field are conducted to determine the condition of groundwater resources in the study area. This survey was conducted to retrieve the geological data of the study area to obtain an overview of the geological characteristics and groundwater potential. Groundwater sampling was carried out at springs and dug well at four locations. Selected springs are moderate or large discharge springs.

Physical / chemical of groundwater laboratory tests were carried out at BBTKLP Yogyakarta Laboratory. Meanwhile, petrological data were obtained directly in the field as well as laboratory descriptions of rock samples. The primary data then analyzed to determine variations in the type of groundwater chemistry and the interpretation of hydrogeological processes using the Stiff, Piper and Durov diagrams.

\section{Regional Geology of Research Area}

The geology of the research area on the West Progo Hills physiography is dominated by materials in the form of Old Andesite Formation (OAF) andesite breccias, tuffs, lapilli tuffs, agglomerates, and intercalation of andesite lava flows and Nanggulan sedimentary rocks (sandstones, claystone). The OAF rocks were formed by ancient volcanic activity in the Tertiary and impermeable. As a result, these materials are not able to store and drain water so groundwater reserves in this region are very minimal. Groundwater in this region is often found in rock fractures [3]. 
The hydrogeological conditions in the Menoreh Hills have low groundwater potential. The steep slope causes rain water that is received by the land surface to gather in river channels and flow downstream rapidly. In this condition, rainwater is not infiltrated into the soil in sufficient quantities.

Meanwhile, the northern part of the study area is included in the central depressive zone which is partly located south of Borobudur Hill. This hill was part of the West Progo Dome which was broken and then sank at the end of the Tertiary Age [1]. Around the broken part, young volcanoes grew in the Quaternary Period, namely Sumbing, Merapi and Merbabu. The broken part eventually becomes the intermountainous basin and forms the ancient lake of Borobudur. These ancient lake deposits are characterized by the presence of black clay deposits [4].

\section{Research Data}

\subsection{Field Data}

Observation location data and lithology are presented in Table 1. Some examples of springs and dug wells examined are shown in Fig. 2.

Table 1. Location of research observations in Borobudur and surrounding areas.

\begin{tabular}{|c|c|c|c|c|c|c|}
\hline \multirow{2}{*}{ Loc. } & \multicolumn{2}{|c|}{ Coordinate } & \multirow{2}{*}{ Area } & \multirow{2}{*}{$\mathbf{p H}$} & \multirow{2}{*}{ TDS } & \multirow{2}{*}{ Lithology } \\
\hline & Longitude & Latitude & & & & \\
\hline S1A & $110^{\circ} 11^{\prime} 13^{\prime \prime}$ & $-7.37^{\prime} 09^{\prime \prime}$ & Karanganyar & 7.4 & 42 & Quaternary sediment \\
\hline S1B & $110^{\circ} 10^{\prime} 56^{\prime \prime}$ & $-7.37^{\prime} 09^{\prime \prime}$ & Karanganyar & 5.5 & 44 & Nanggulan sandstone \\
\hline $\mathrm{R} 2$ & $110^{\circ} 10^{\prime} 28^{\prime \prime}$ & $-7.37^{\prime} 25^{\prime \prime}$ & Badrawati & 9.6 & 31 & Quaternary sediment \\
\hline W3 & $110^{\circ} 10^{\prime} 05^{\prime \prime}$ & $-7.37 ' 36^{\prime \prime}$ & Giri Tengah & 10.7 & 41 & Quaternary sediment \\
\hline $\mathrm{R} 4$ & 110.09'27' & $-7 \cdot 36^{\prime} 48^{\prime \prime}$ & Giri Tengah & 10.8 & 40 & Quaternary sediment \\
\hline W5 & $110^{\circ} 10^{\prime} 28^{\prime \prime}$ & $-7.36^{\prime} 52^{\prime \prime}$ & Ngadiharjo & 5.4 & 94 & Quaternary sediment \\
\hline S6 & $110^{\circ} 10^{\prime} 46^{\prime \prime}$ & $-7 \cdot 36^{\prime} 37^{\prime \prime}$ & Karanganyar & 8.6 & 37 & Quaternary sediment \\
\hline W7 & $110^{\circ} 10^{\prime} 38^{\prime \prime}$ & $-7 \cdot 36^{\prime} 17^{\prime \prime}$ & Karangrejo & 5 & 1326 & Quaternary sediment \\
\hline W8 & 110.09'49”' & $-7 \cdot 35^{\prime} 48^{\prime \prime}$ & Kembanglimus & 4.6 & 134 & Quaternary sediment \\
\hline S9 & $110^{\circ} 09^{\prime} 52^{\prime \prime}$ & $-7 \cdot 36^{\prime} 14^{\prime \prime}$ & Kembanglimus & 6.4 & 27 & Quaternary sediment \\
\hline W10 & $110^{\circ} 10^{\prime} 11^{\prime \prime}$ & $-7.36^{\prime} 15^{\prime \prime}$ & Tawangsari & 6.1 & 49 & Quaternary sediment \\
\hline W11 & $110^{\circ} 09^{\prime} 48^{\prime \prime}$ & $-7.37^{\prime} 33^{\prime \prime}$ & Karangrejo & 6.6 & 39 & Nanggulan sandstone \\
\hline S12 & $\begin{array}{c}110 \mathrm{o} 10 \\
14 "\end{array}$ & -7 o $36^{\prime} 37^{\prime \prime}$ & Giri Tengah & 12.6 & 19 & Quaternary sediment \\
\hline W13 & $\begin{array}{c}\text { 110o } 09^{\prime} \\
48 "\end{array}$ & -7 o $36^{\prime} 45^{\prime \prime}$ & Karanganyar & 7.6 & 99 & Quaternary sediment \\
\hline
\end{tabular}


Table 1. (Continued)

\begin{tabular}{|c|c|c|c|c|c|c|}
\hline \multirow{2}{*}{ Loc. } & \multicolumn{2}{|c|}{ Coordinate } & \multirow{2}{*}{ Area } & \multirow{2}{*}{$\mathbf{p H}$} & \multirow{2}{*}{ TDS } & \multirow{2}{*}{ Litology } \\
\hline & Longitude & Latitude & & & & \\
\hline S14 & $110^{\circ} 09^{\prime} 27^{\prime \prime}$ & $-7 \cdot 37 ' 11^{\prime \prime}$ & Ngadiharjo & 5.2 & 93 & Quaternary sediment \\
\hline W15 & $110^{\circ} 09^{\prime} 62^{\prime \prime}$ & $-7 \cdot 37^{\prime} 26^{\prime \prime}$ & Ngadiharjo & 4.5 & 79 & Quaternary sediment \\
\hline W16 & 110 09'04”' & $-7 \cdot 36^{\prime} 51^{\prime \prime}$ & Giri Tengah & 5.1 & 72 & Quaternary sediment \\
\hline W17 & $110^{\circ} 08^{\prime} 48^{\prime \prime}$ & $-7.36^{\prime} 07^{\prime \prime}$ & Ngadiharjo & 5.8 & 76 & Quaternary sediment \\
\hline W18 & $110^{\circ} 08^{\prime} 48^{\prime \prime}$ & $-7.35^{\prime} 49^{\prime \prime}$ & Paripurna & 5.3 & 56 & Quaternary sediment \\
\hline W19 & $110^{\circ} 08^{\prime} 30^{\prime \prime}$ & $-7 \cdot 36^{\prime} 56^{\prime \prime}$ & Paripurna & 5.9 & 61 & Andesite breccia OAF \\
\hline R20 & $110^{\circ} 08^{\prime} 22^{\prime \prime}$ & $-7 \cdot 37^{\prime} 07^{\prime \prime}$ & Paripurna & 5.4 & 48 & Quaternary sediment \\
\hline S21 & $110^{\circ} 08^{\prime} 07^{\prime \prime}$ & $-70^{\prime} 52^{\prime \prime}$ & Paripurna & 5.5 & 14 & Quaternary sediment \\
\hline S22 & $110^{\circ} 07^{\prime} 25^{\prime \prime}$ & $-7 \circ 36^{\prime} 56^{\prime \prime}$ & Paripurna & 5.2 & 17 & Quaternary sediment \\
\hline S23 & $110^{\circ} 07^{\prime} 34^{\prime \prime}$ & $-7 \cdot 36^{\prime} 16^{\prime \prime}$ & Paripurna & 4.9 & 23 & Quaternary sediment \\
\hline R24 & $110^{\circ} 08^{\prime} 25^{\prime \prime}$ & $-7 \cdot 36^{\prime} 20^{\prime \prime}$ & Paripurna & 5.1 & 15 & Andesite of OAF \\
\hline $\mathrm{R} 25$ & $110^{\circ} 13^{\prime} 27^{\prime \prime}$ & $-7 \cdot 37^{\prime} 35^{\prime \prime}$ & Paripurna & 4.9 & 49 & Nanggulan claystone \\
\hline S26 & $110^{\circ} 13^{\prime} 33^{\prime \prime}$ & $-7 \cdot 37^{\prime} 32^{\prime \prime}$ & Candirejo & 6,8 & 1430 & $\begin{array}{c}\text { Andesite breccia of } \\
\text { OAF }\end{array}$ \\
\hline W27 & $110^{\circ} 13^{\prime} 22^{\prime \prime}$ & $-7.36^{\prime} 50^{\prime \prime}$ & Candirejo & 6.5 & 165 & Quaternary sediment \\
\hline W28 & $110^{\circ} 08^{\prime} 33^{\prime \prime}$ & $-7.37^{\prime} 01^{\prime \prime}$ & Candirejo & 6.7 & 54 & Quaternary sediment \\
\hline W29 & $110^{\circ} 11^{\prime} 06^{\prime \prime}$ & $-7 \cdot 36^{\prime} 26^{\prime \prime}$ & Paripurna & 7.4 & 42 & Nanggulan Sandstone \\
\hline
\end{tabular}

Note: S: spring; W: well; R: river

Groundwater found at the S1A location (Fig. 2a) appears on the sediment, is rather turbid, brownish in color, but tasteless and odorless. Groundwater $\mathrm{pH}$ value is 7.4, while TDS is $42 \mathrm{ppm}$. The spring in Paripurno Village (Fig. 2b) shows odorless, clear, with a relatively acidic $\mathrm{pH}(5.5)$ and a low TDS (17 ppm). Different condition occurs in Candirejo spring (S26) where the groundwater shows brown, turbid, odorless but rather salty, $\mathrm{pH} 6.8$ and TDS measured in the field at $1430 \mathrm{ppm}$.

Groundwater from dug wells found in Karangrejo (W7) and Kembanglimus (W8) shows colorless, clear and odorless characteristics. Groundwater in W7 tastes a bit salty, but groundwater in W8 does not taste. The measured $\mathrm{pH}$ in groundwater at $\mathrm{W} 7$ and $\mathrm{W} 8$ is 5 and 4.6, while the TDS is measured at 1326 and $134 \mathrm{ppm}$. The two wells tapped water from Quaternary deposits, but differed in salinity. The presence of brackish groundwater is localized [5], mentioned that the distribution of groundwater quality in a place is not always easy to model, even the presence of brackish water is not always related to morphology. 

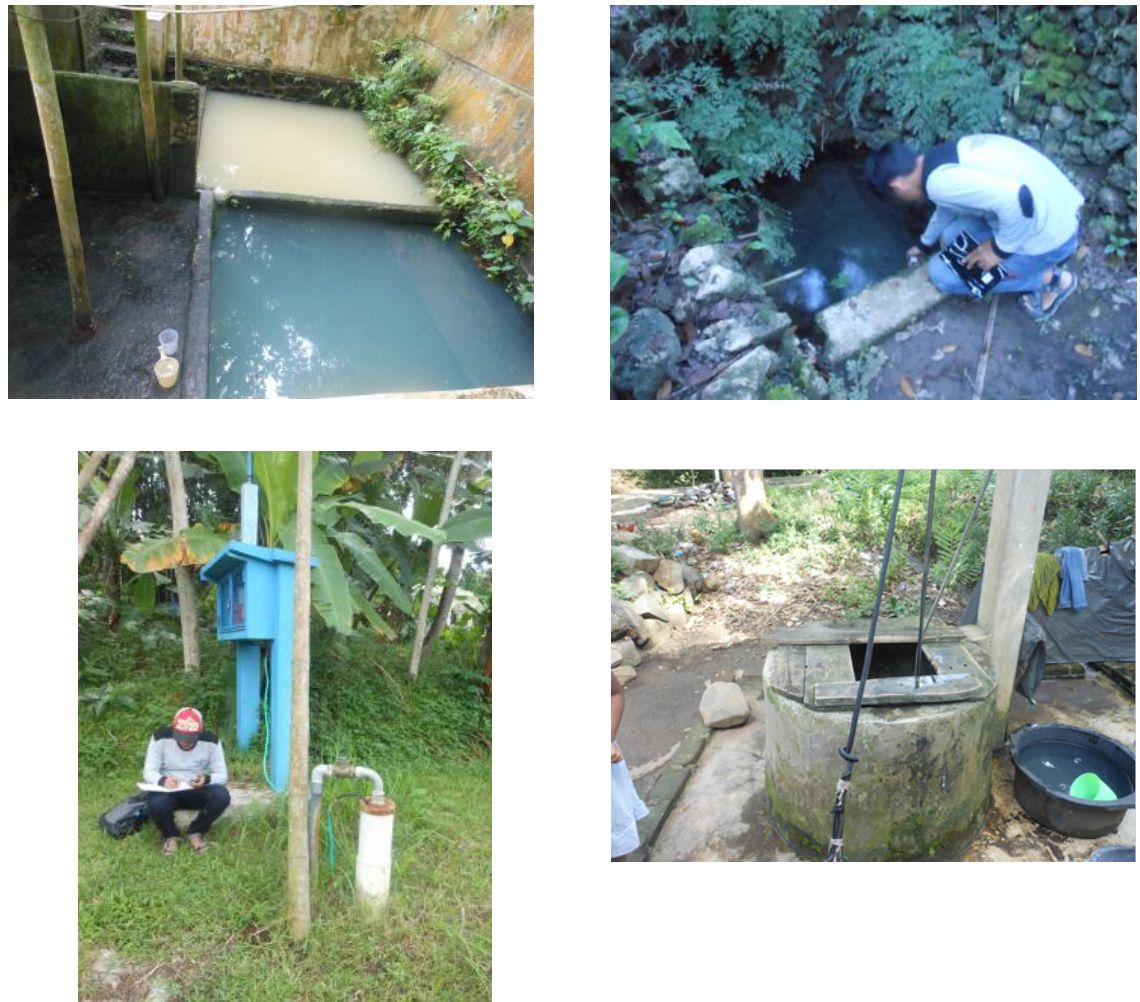

Fig. 2. Springs found at (clockwise): a. Karanganyar Village (S1A); b. Paripurno (S22); c. Karangrejo (W7); and d. Kembanglimus (W8).

\subsection{Laboratory Data}

The laboratory test results of physical / chemical of groundwater are presented in Table 2. Physically, groundwater in the study area is generally tasteless to brackish, and odorless. Groundwater $\mathrm{pH}$ values tend to vary from normal to acidic. The groundwater studied was clear to turbid, with TDS varying from small to large enough.

The types of groundwater chemistry studied were highly variable (Table 2), namely Ca, $\mathrm{Mg}$ bicarbonate; $\mathrm{Ca}, \mathrm{Mg}$, alkaline - bicarbonate; alkaline, $\mathrm{Ca}$ - chloride and alkaline chloride. The dominant major cations composing groundwater vary greatly, while the major anions are dominated by bicarbonate and chloride ions.

Table 2 also shows that the groundwater samples had greatly varied TDS from 119 to $6810 \mathrm{ppm}$. According to Caroll's classification (1962, in [6]) the groundwater is fresh to brackish water.

Meanwhile, the carbonate hardness of the groundwater was $6-16.57 \mathrm{ppm}$ or $<75 \mathrm{ppm}$. According to the Sawyer \& Mc. Carty (1967, in [6]), it is soft groundwater. This means that there are not enough carbonate ion sources in the study area. The carbonate rocks in which groundwater passes through are only a thin layer of carbonate sandstone or claystone of the Nanggulan Formation.

Table 2 also shows that the groundwater samples had greatly varied TDS from 119 to $6810 \mathrm{ppm}$. According to Caroll's classification (1962, in [6]) the groundwater is fresh to brackish water. 
Table 2. Physical / chemical data of groundwater test results in the laboratory.

\begin{tabular}{|c|c|c|c|c|c|}
\hline \multirow{2}{*}{ No } & \multirow{2}{*}{ Parameter } & \multicolumn{4}{|c|}{ Sample } \\
\hline & & S1A & S1B & W7 & S26 \\
\hline 1 & $\mathrm{Ca}^{2+}(\mathrm{ppm})$ & 20.1 & 21.71 & 107.74 & 45.02 \\
\hline 2 & $\mathrm{Na}^{+}(\mathrm{ppm})$ & 20 & 21 & 503 & 2294 \\
\hline 3 & $\mathrm{~K}^{+}(\mathrm{ppm})$ & 3 & 3 & 12 & 82 \\
\hline 4 & $\mathrm{Mg}^{2+}(\mathrm{ppm})$ & 11.23 & 9.77 & 9.28 & 23.93 \\
\hline 5 & $\mathrm{Cl} \cdot(\mathrm{ppm})$ & 8.5 & 13 & 1742.5 & 4198.7 \\
\hline 6 & $\mathrm{HCO}_{s}(\mathrm{ppm})$ & 108.2 & 96.2 & 276.4 & 156.3 \\
\hline 7 & $\mathrm{SO}_{4^{-2}}(\mathrm{ppm})$ & 6 & 1 & 88 & 1 \\
\hline \multirow{2}{*}{8} & \multirow{2}{*}{ TDS (ppm) } & 119 & 129 & 2840 & 6810 \\
\hline & & fresh & fresh & brackish & brackish \\
\hline \multirow{3}{*}{10} & \multirow{3}{*}{$\begin{array}{l}\mathrm{pH} \\
\text { Hardness }\end{array}$} & 5.7 & 5.5 & 6.5 & 6.4 \\
\hline & & 6.30 & 6.00 & 16.57 & 13.69 \\
\hline & & soft & soft & soft & soft \\
\hline 11 & Chemical type & $\begin{array}{c}\mathrm{Ca}, \mathrm{Mg}- \\
\text { bicarbonate }\end{array}$ & $\begin{array}{l}\mathrm{Ca}, \mathrm{Mg} \text {, alkaline } \\
\text { - bicarbonate }\end{array}$ & $\begin{array}{l}\text { Alkaline, } \mathrm{Ca} \\
\text { - chloride }\end{array}$ & $\begin{array}{l}\text { Alkaline- } \\
\text { chloride }\end{array}$ \\
\hline
\end{tabular}

Meanwhile, the carbonate hardness of the groundwater was $6-16.57 \mathrm{ppm}$ or $<75 \mathrm{ppm}$. According to the Sawyer \& Mc. Carty (1967, in [6]), it is soft groundwater. This means that there are not enough carbonate ion sources in the study area. The carbonate rocks in which groundwater passes through are only a thin layer of carbonate sandstone or claystone of the Nanggulan Formation.

\section{Hydrochemical of Groundwater}

\subsection{Stiff diagram Analysis}

The study of water chemistry begins with looking at the chemical content of major ions in groundwater. The following Table 2 are resumes of chemical elements / compounds, $\mathrm{pH}$, TDS, hardness, and types of groundwater chemistry. The type of groundwater chemistry turned out to have wide variations. Considerable differences in the content of chemical elements can also be seen clearly on the Stiff diagram (Figure 3).

The dominance of the bicarbonate anion shows that groundwater in several places in the study area is generally new groundwater, which comes from precipitation in recharge area. This groundwater comes from rainwater that falls in the local area, so it has a relatively young age. However, a large alkali content indicates that there is already a process of enrichment of these elements through a hydrochemical process.

Brackish groundwater is interpreted as groundwater that has undergone evolution or enrichment in salinity. This can occur through the process of ion exchange due to the interaction / prolonged contact between groundwater to the rocks in its path [5]. 


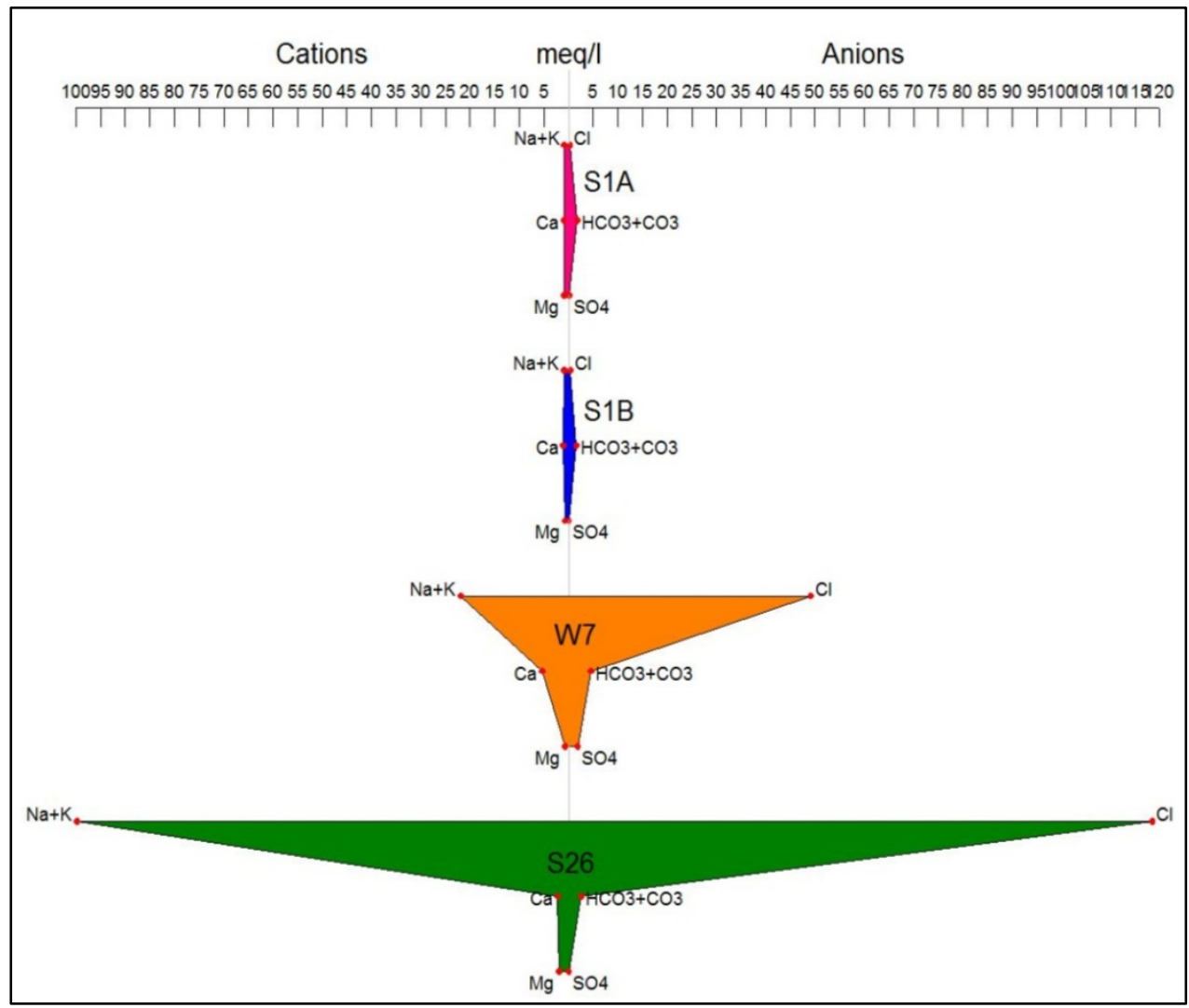

Fig. 3. Stiff diagram of groundwater samples.

\subsection{Trilinier Piper Diagram Analysis}

This analysis method is important for groundwater genetic studies and geochemical problems [7]. The interpretation of groundwater quality types can be determined by observing the dominant group of data plotting results in the parallelogram of Piper diagram. The chemical plots of major elements contained in the groundwater are presented in Figure 4.

According to the Piper diagram, groundwater from springs in Karanganyar (S1A, S1B) is included in 1, 3, 5 classes (Table 3), while groundwater that is found in W7 dug well (Karangrejo) and spring in S26 (Candirejo) are included in type 2, 4, and 7 water classes. From the diagram it appears that groundwater in Karanganyar is freshwater with a few mixing processes. This is supported by the relatively low TDS value, which is around 119 129 ppm according to Carroll (1962, in [6]). The dominant processes occurring in groundwater in Karanganyar are leaching and mixing.

The groundwater from Karangrejo well and Candirejo spring is almost saline according to the Piper diagram or brackish groundwater refers to Carroll classification (1962, in [6]) with TDS 2840 and $6810 \mathrm{ppm}$. Both types of groundwater are the result of the mixing process or fossil water, but they are far from sea water intrusion process (Figure 4). 


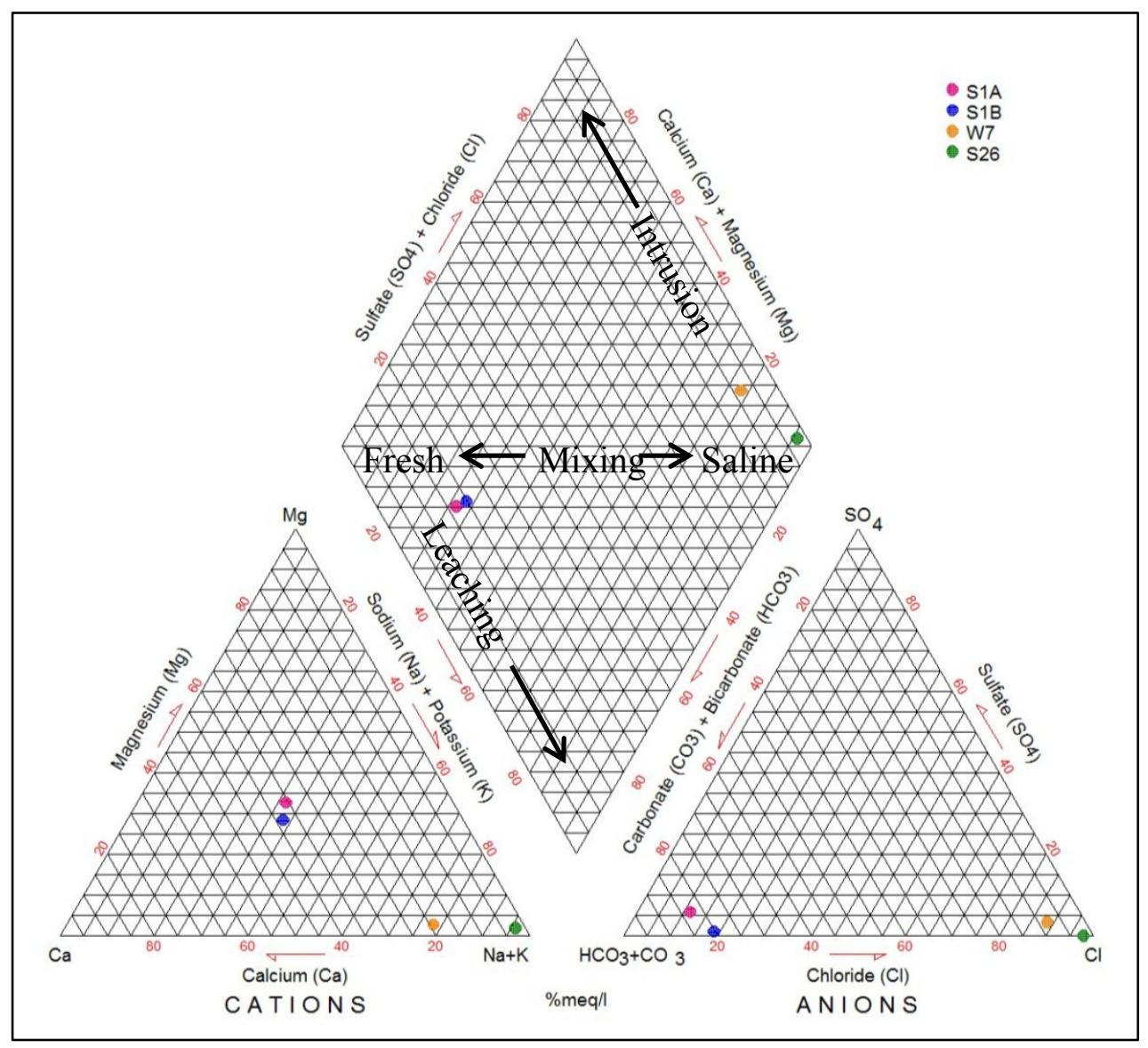

Fig. 4. Plot data of groundwater in Piper diagram.

Table 3. Types of groundwater chemistry in the study area.

\begin{tabular}{|c|c|c|c|c|c|}
\hline \multicolumn{2}{|c|}{ Location } & \multicolumn{2}{|c|}{ Type } & \multirow{2}{*}{\multicolumn{2}{|c|}{ Facies }} \\
\hline No & Village & Cations & Anions & & \\
\hline \multirow[t]{3}{*}{$\begin{array}{l}\text { S1A } \\
\text { S1B }\end{array}$} & \multirow[t]{3}{*}{ Karanganyar } & \multirow{3}{*}{$\begin{array}{l}\text { D type (No } \\
\text { dominant } \\
\text { type) }\end{array}$} & \multirow{3}{*}{$\begin{array}{l}\text { E type } \\
\text { (Bicarbonate } \\
\text { type) }\end{array}$} & 1 & $\begin{array}{l}\text { Alkaline earths }\left(\mathrm{Ca}^{2+}+\mathrm{Mg}^{2+}\right) \text { exceed } \\
\text { alkaline }\left(\mathrm{Na}+\mathrm{K}^{+}\right) \text {. }\end{array}$ \\
\hline & & & & 3 & $\begin{array}{l}\text { Weak acids }\left(\mathrm{CO}_{3^{2}}+\mathrm{HCO}_{3}\right) \text { exceed } \\
\text { strong acids }\left(\mathrm{SO}_{4^{2}}+\mathrm{Cl}\right) .\end{array}$ \\
\hline & & & & 5 & $\begin{array}{l}\text { Magnesium bicarbonate type with } \\
\text { carbonate hardness (secondary } \\
\text { alkalinity) }>50 \% \text {, groundwater is } \\
\text { dominated by alkaline soils }\left(\mathrm{Ca}^{2+}+\right. \\
\left.\mathrm{Mg}^{2+}\right) \text { and weak acids }\left(\mathrm{CO}_{3^{2}}+\mathrm{HCO}_{3}\right) \text {. }\end{array}$ \\
\hline
\end{tabular}


Table 3. (Continued)

\begin{tabular}{|c|c|c|c|c|c|}
\hline \multicolumn{2}{|c|}{ Location } & \multicolumn{2}{|c|}{ Type } & \multirow{2}{*}{\multicolumn{2}{|c|}{ Facies }} \\
\hline No & Village & Cations & Anions & & \\
\hline \multirow[t]{3}{*}{$\begin{array}{l}\text { W7 } \\
\text { S26 }\end{array}$} & \multirow[t]{3}{*}{$\begin{array}{l}\text { Karangrejo } \\
\text { Candirejo }\end{array}$} & \multirow{3}{*}{$\begin{array}{l}\text { C type } \\
\text { (Sodium \& } \\
\text { potassium / } \\
\text { Alkaline } \\
\text { type) }\end{array}$} & \multirow{3}{*}{$\begin{array}{l}\text { G type } \\
\text { (Chloride } \\
\text { type) }\end{array}$} & 2 & $\begin{array}{l}\text { Alkali }\left(\mathrm{Na}^{+}+\mathrm{K}^{+}\right) \text {exceeds the alkaline } \\
\text { earth }\left(\mathrm{Ca}^{++}+\mathrm{Mg}^{2+}\right) \text {. }\end{array}$ \\
\hline & & & & 4 & $\begin{array}{l}\text { Strong acids }\left(\mathrm{SO}_{t^{2}}+\mathrm{Cl}\right) \text { exceed } \\
\text { weak acids }\left(\mathrm{CO}_{3^{2}}+\mathrm{HCO}_{3}\right) \text {. }\end{array}$ \\
\hline & & & & 7 & $\begin{array}{l}\text { Sodium chloride type with non- } \\
\text { carbonate alkali (primary salinity) }> \\
50 \% \text {, the chemical properties of } \\
\text { groundwater are predominantly } \\
\text { alkaline }\left(\mathrm{Na}^{+}+\mathrm{K}^{+}\right) \text {and strong acids } \\
\left(\mathrm{SO}_{4^{2-}}+\mathrm{Cl}\right) .\end{array}$ \\
\hline
\end{tabular}

\subsection{Piper Quadrangle Diagram Analysis}

Piper's trilinier method has been developed into a quadrangle system [8] (Fig. 5), by dividing groundwater hydrochemicals into 6 hydrochemical types. According to this Piper rectangular diagram, groundwater is included in class V (fossil / connate water). Groundwater in Karanganyar is included in type Va, while groundwater in Karangrejo and Candirejo is included in type Vc.

According to Piper's quadrilateral diagram, the S1A and S1B groundwater samples from Karanganyar springs are included in the fossil water type, but are still close to group I (bicarbonate water). Groundwater is included in the Va type, although including bicarbonate facies, but this groundwater contains a fairly large alkaline elements. The presence of a large enough alkali can be sourced from feldspar minerals, clay minerals or rock fragments (Bowen, 1986 in [9]). Feldspar minerals are easily weathered silicate minerals, according to Goldich sequence weathering (Goldich, 1938, in [10]).

Although dominated by bicarbonate ions, groundwater in Karanganyar is not solely supplied by rainwater, but there is a cation exchange process that accompanies it. This condition is very likely to occur, because the local aquifer is clayey Quaternary sediments. These sediments are generally part of ancient lake sediments [4]. The tendency of groundwater to be of type $\mathrm{Va}$ is much controlled by the cation exchange process. The ion exchange processes in groundwater particularly occur in clay minerals [11]. The high salinity in the groundwater can also be supported by the existence of a deaquation process (Drever, 1988 in [12]). Some salt / brackish water events can also occur due to salt concentration through the process of salt sieving in fine-grained sediments [13].

\subsection{Durov Diagram Analysis}

The Durov diagram is almost similar to the Piper diagram because it also uses a trilinier diagram. In this diagram we can see the existence of a hydrochemical process that mainly occurs in the study area (Fig. 6).

The groundwater sample plot from the Karanganyar spring enters area 2 in the diagram which means that the groundwater has the dominant characteristics of $\mathrm{HCO}_{3}{ }^{-}, \mathrm{Ca}^{2+}$ and $\mathrm{Mg}^{2+}$ which are quite large, associated with certain minerals. $\mathrm{Ca}^{2+}$ and $\mathrm{Na}^{+}$are an important part of the ion exchange process [13]. In addition to ion exchange, groundwater in the Karanganyar area undergoes a simple dissolution or mixing process. 


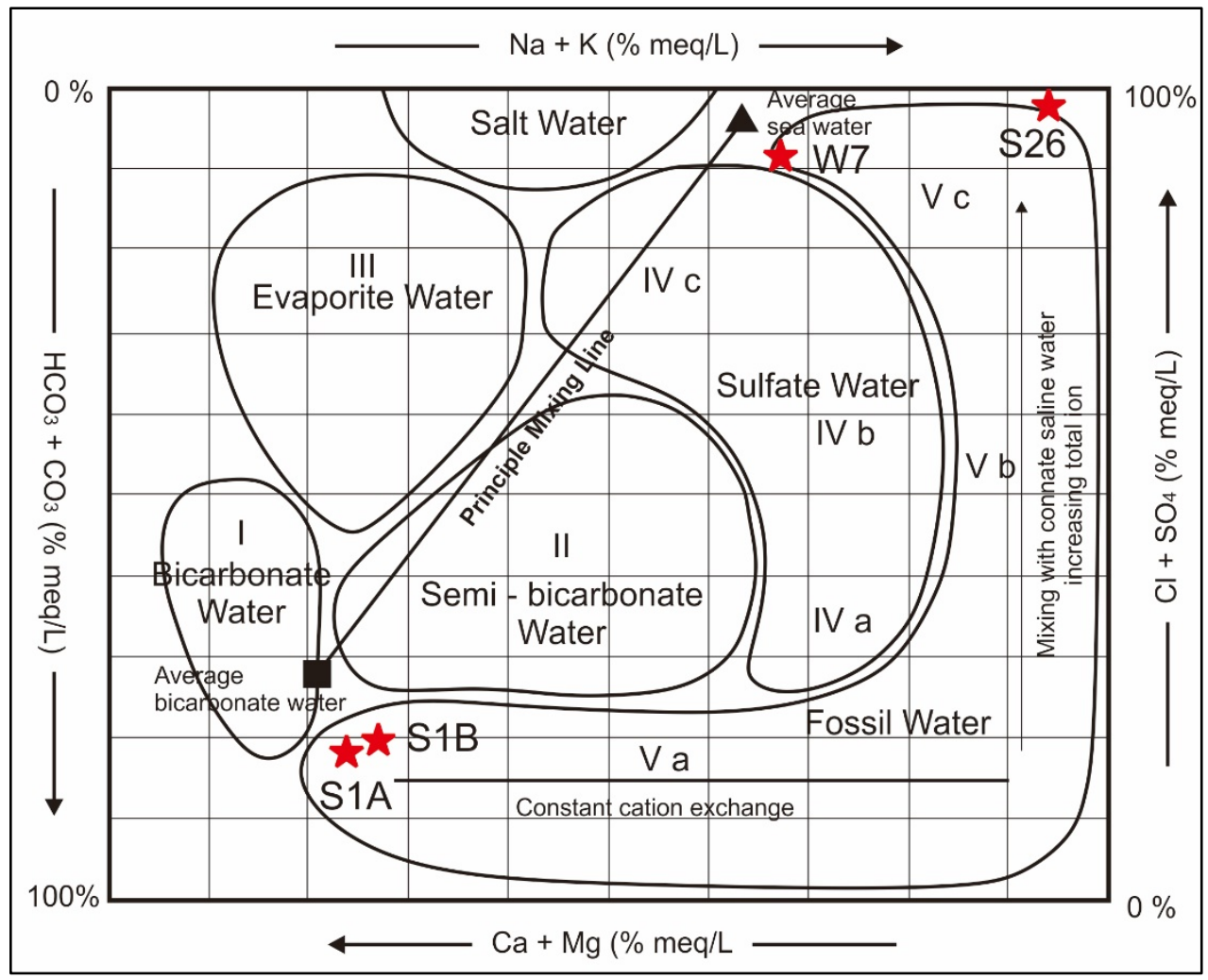

Fig. 5. The hydrochemical type of groundwater on a rectangular Piper diagram.

The groundwater samples from the Karangrejo well and Candirejo springs enter area 9, which means that the groundwater is the result of an advanced process of simple dissolution or mixing. This area shows that $\mathrm{Cl}^{-}$and $\mathrm{Na}^{+}$are dominant and often mark end-point waters.

The Durov diagram shows that the ion exchange process is an important process in freshwater in the study area. This might happen to Quaternary volcanic rocks or sediments which contain a lot of clay minerals. Porous geological material composed of a number of colloidal sized particles such as clay minerals has the ability to exchange ions that are absorbed on the particle surface. Clay minerals generally exhibit surface charges due to ion substitution [14]. The tendency of ion adsorption depends on the $\mathrm{pH}$ of the solution. Variations in the number and types of ions will reflect the composition of ions in the clayey sediments.

The simple dissolution or mixing process shown in brackish groundwater at Karangrejo and Candirejo is supported by clay material derived from Quaternary sediments or weathered volcanic breccia of the Old Andesite Formation. The process can take a long time so that the evolution of anions tends to be the hydrochemical type of sea water.

Rocks in the study area can function as aquifers. The results of weathered aquifer and non-aquifer rocks can produce clay material that supports the ion exchange process. The aquifer found in Karanganyar shows the size of sand grains with high porosity and permeability, supported by intergrain pores. Many springs in the study area are supported by Quaternary aquifer like this conditions. In addition to Quaternary deposits, compact rocks such as OAF andesite breccias and Nanggulan sandstones can also function as aquifers. 


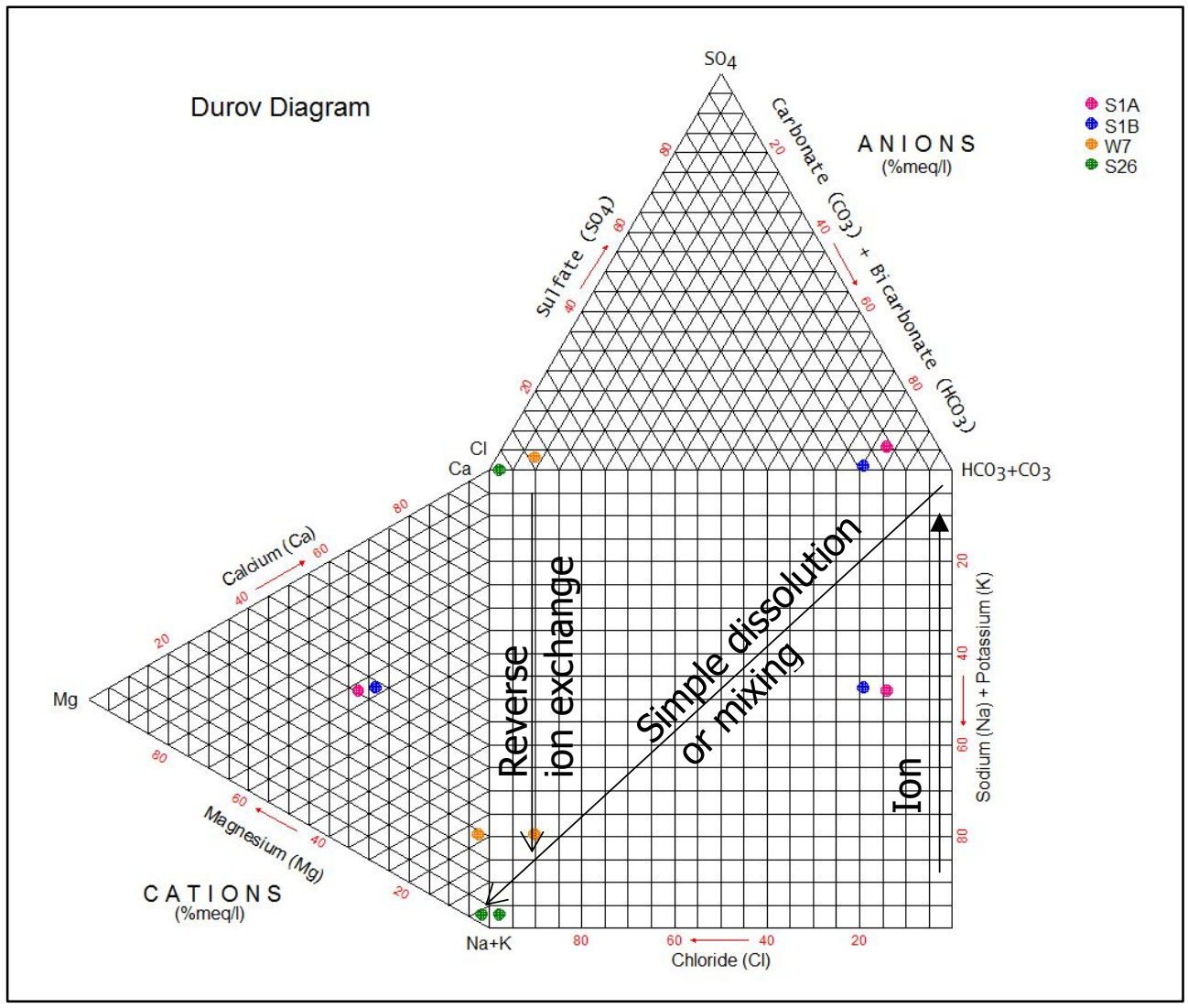

Fig. 6. Plot of groundwater data in Durov diagram (Lloyd \& Heathcote, 1985).

Based on several analyzes before, it appears that groundwater in the study area has a wide variation in chemical types. This is influenced by the varying hydrochemical processes as groundwater travel below the surface. The existence of fresh groundwater is usually associated with local precipitation where rainfall still dominates the type of groundwater chemistry. Groundwater in Karanganyar with bicarbonate facies is young groundwater but there is already an influence on the process of alkaline ion enrichment of soluble mineral feldspar through long water-rock interaction.

Meanwhile, brackish water can be caused by ion exchange processes in Quaternary clay deposits or claystone that can affect groundwater quality through water-rock interaction process. This is supported by the presence of Nanggulan claystone around the Candirejo spring. The process of ion exchange between groundwater and rocks in its path is very easy to occur in clay minerals [12].

The presence of alkali ions $(\mathrm{Na}, \mathrm{K})$ is quite dominant in groundwater is usually comes from the weathering of silicate rocks [10]. Furthermore, Grim (1953, in [9]) says that the weathering process is an example of an ion exchange process that involves the release of alkali or alkaline earth ions. It may be mainly controlled by weathering and balance of evaporation-precipitation conditions [15]. Feldspar is an influential source of alkaline ions [12]. A longer period of water-rock reaction can occur as long as groundwater flows below the surface and results in the enrichment of ions in it. 


\section{Summary}

Groundwater in the study area has a cation element that varies from one place to another, with the dominant anion of bicarbonate or chloride. The types of groundwater chemistry in the study area varied greatly including $\mathrm{Ca}, \mathrm{Mg}$ - bicarbonate; $\mathrm{Ca}, \mathrm{Mg}$, alkaline bicarbonate; alkaline, Ca-chloride and alkaline chloride.

Groundwater salinity in the study area varies from fresh to brackish. The chemical content of the groundwater in Karanganyar is supported by low TDS, freshwater with type $\mathrm{Va}$. The dominance of bicarbonate ions shows that this groundwater is much influenced by precipitation, but there are already indications of mixing or ion exchange processes. This groundwater is young which is affected by the process of long enough water - rocks interaction or soluble minerals. The physical / chemical character of groundwater is influenced by the presence of Old Andesite and Nanggulan Formation rocks as well as clay deposits which support the cation exchange process.

Brackish groundwater is also found in the Vc type in research areas, especially in Karangrejo and Candirejo. This groundwater has a high TDS, but is still soft. The groundwater is the result of simple dissolution or mixing processes in the advanced phase. The process of ion exchange and mixing with fossil water is also possible in this area. The ion exchange process develops because of the large amount of clay content in Quaternary deposits.

\section{Acknowledgment}

This paper is based on the results of research in 2016 by funding of Kopertis V Yogyakarta, therefore the authors would like to thank for the support of Kopertis V and STTNAS Yogyakarta so that this paper can be completed.

\section{References}

1. Van Bemmelen, R.W., 1949, The Geology of Indonesia, Vol. 1A, Martinus Nijhoff, The Hague, Netherland.

2. Badan Geologi, 2011, Atlas Cekungan Air Tanah Indonesia, Kementrian Energi dan Sumber Daya Mineral, Bandung, ISSN 987-602-9105-09-4.

3. Anonymous, 2014, Gambaran Umum Kabupaten Kulon Progo, http://www. ppsp.nawasis.info.

4. Murwanto, H., Purwoarminta, A. and Siregar, D.A., 2014, Tectonics and landslides control of the landform changes in the southern part of Borobudur ancient lake, Jurnal Lingkungan dan Bencana Geologi, Vol. 5 No. 2 Agustus (2014): 143 - 158.

5. Yogafanny, E., Novianto, A., Ernawati, R., Nandari, W.W., 2019, The Hydrochemistry of Groundwater in Jambakan, Klaten Regency, Central Java Province, Indonesia, Journal of Geoscience, Engineering, Environment, and Technology, Vol. 04, No. 04, pp. $277-284$.

6. Todd, D.K., 1980, Groundwater Hydrology, $2^{\text {nd }}$ Ed., John Willey \& Sons Inc., New York, $535 \mathrm{p}$.

7. Suharyadi, 1984, Geohidrologi (Ilmu Airtanah), Department of Geological Engineering, Engineering Faculty, Gadjah Mada University, Yogyakarta.

8. Kloosterman, F. H. 1983. Reconnaissance Study of Groundwater Resources in the Kabupaten Cirebon. Provincial Health Service Directorate CDC, Bandung.

9. Listyani, T., 2016, Hydrochemistry of Groundwater in Geyer, Grobogan Province, Central Java, Kurvatek, Vol. 1, No. 2, pp. 13 - 19, STTNAS, Yogyakarta, November 2016; https://journal.sttnas.ac.id/krvtk/article/view/230/pdf_1 
10. Appelo, C.A.J. dan Postma, D. 2005. Geochemistry, Groundwater and Pollution, $2^{\text {nd }}$ Edition, Amsterdam: A.A. Balkema.

11. Listyani, T., 2016, Rock's Mineral Control on Groundwater Quality in Jakarta Groundwater Basin, Prosiding Seminar Nasional Rekayasa Teknologi Industri dan Informasi (ReTII) ke 11, STTNAS Yogyakarta, ISSN 1907-5995, 10 Desember 2016, https://journal.sttnas.ac.id/ReTII/article/view/500/425

12. 14. Freeze, R.A. and Cherry, J.A., 1979, Groundwater, Prentice-Hall, Inc., Englewood Cliffs, New Jersey, 604 p.

13. Listyani R.A., T., 2004, Proses Pertukaran Kation pada Mineral Lempung dan Kontribusinya dalam Geohidrologi, Jurnal Teknologi Nasional, Vol. 7, No. 2, STTNAS Yogyakarta, April (2004).

14. Lloyd, J.W. \& Heathcote, J.A., 1985, Natural Inorganic Hydrochemistry in Relation to Groundwater, an Introduction, Clarendon Press - Oxford.

15. Siringoringo, L.P., Rizki, R. and Nababan, J., 2019, Hydrogeochemical and Groundwater Assessment for Drinking Purpose at ITERA Campus Area and Its Surroundings, Journal of Geoscience, Engineering, Environment, and Technology, Vol. 04, No. 01, pp. $40-48$. 